\title{
Unsuspected Pneumocystis carinii pneumonia at presentation of severe primary immunodeficiency
}

\author{
Janet E Berrington, Terence J Flood, Mario Abinun, Angela Galloway, Andrew J Cant
}

\begin{abstract}
Background-Pneumocystis carinii is an important pathogen in immunodeficiency but may be an unrecognised cause of respiratory compromise.

Objectives-To ascertain the incidence of $P$ carinii pneumonia (PCP) at presentation of severe combined immunodeficiency (SCID), whether it had been diagnosed, and the effect of treatment on outcome.

Setting-The supraregional paediatric bone marrow transplant unit for primary immunodeficiencies at Newcastle General Hospital.

Methods-Retrospective case note review of infants referred with a diagnosis of SCID from 1992 to 1998.

Results-Ten of 50 infants had PCP at presentation; only one was diagnosed before transfer. Eight were diagnosed by bronchoalveolar lavage and two by lung biopsy. In only one was $P$ carinii identified in nasopharyngeal secretions. Five required ventilation for respiratory failure but all were successfully treated with co-trimoxazole and methylprednisolone with or without nebulised budesonide. Nine survived to bone marrow transplantation and four are long term survivors after bone marrow transplantation; no deaths were related to PCP.

Conclusions-PCP is a common presenting feature of SCID but is rarely recognised. Bronchoalveolar lavage or lung biopsy are needed for diagnosis. Treatment with co-trimoxazole is highly successful.

(Arch Dis Child 2000;82:144-147)
\end{abstract}

Paediatric

Immunology and

Infectious Diseases

Unit, Newcastle

General Hospital,

Westgate Road,

Newcastle upon Tyne

NE4 6BE, UK

J E Berrington

T J Flood

M Abinun

A J Cant

Newcastle Public Health Laboratory, Newcastle upon Tyne, UK

A Galloway

Correspondence to: Dr Cant

email: a.j.cant@ncl.ac.uk

Accepted 10 September 1999
Keywords: Pneumocystis carinii; pneumonia; severe combined immunodeficiency

Pneumocystis carinii is an important opportunistic pathogen in patients with poor $\mathrm{T}$ lymphocyte function as a result of either primary or secondary immunodeficiency. ${ }^{1}$ The association of unsuspected $P$ carinii pneumonia (PCP) with HIV infection has been highlighted. ${ }^{2}$ Here, we would like to highlight the importance of PCP as the presenting manifestation of a severe combined primary immune defect in infants born into populations not at high risk of HIV infection.

\section{Methods}

A retrospective case note study was undertaken of 50 infants with severe combined immunodeficiency disease (SCID), referred as emer- gencies for confirmation of their diagnosis and subsequent management, between 1992 and 1998. Depending on respiratory symptoms and signs, microbiological investigation included nasopharyngeal secretions (obtained by standardised nasal wash) and bronchoalveolar lavage fluid sent for bacterial, fungal, and mycobacterial microscopy and culture, and screening for cytomegalovirus early antigen and respiratory syncytial virus, influenza A and B viruses, adenovirus, parainfluenza viruses $1,2,3$, and 4 , and herpes simplex virus by direct immunofluorescence and/or cell culture. $P$ carinii was detected by immunofluorescence using a monoclonal antibody. The bronchoalveolar lavage was performed in all infants with respiratory symptoms using a standardised procedure at the time of ventilation in infants whose respiratory function dictated this, or at the time of intubation for anaesthesia at surgical central venous cannulation, after informed consent. Open lung biopsy was performed when a respiratory pathogen was not detected in bronchoalveolar lavage fluid despite strong clinical suspicion.

Case notes of infants in whom $P$ carinii was detected were reviewed in detail, and the following were ascertained: age at presentation to Newcastle General Hospital, ethnic group, parental consanguinity, family history of SCID or unexplained infant death, duration and nature of respiratory symptoms, results of respiratory investigations before transfer, treatment before transfer, clinical status at transfer, results of investigations after transfer, treatment given, underlying diagnosis, and outcome.

\section{Representative case histories}

CASE A

A 10 month old white infant (patient 6 in table 1) born to unrelated parents with no family history suggestive of immunodeficiency was admitted to his local hospital with a 10 day history of cough and respiratory distress, requiring supplementary oxygen. Interstitial pneumonitis was present on chest radiography but no pathogens were isolated from nasopharyngeal secretions. Treatment was commenced with cefotaxime and azithromycin. A history of recurrent oral and perianal thrush and a buttock abscess prompted investigation of his immune system, which disclosed an absence of $\mathrm{T}$ lymphocytes. $\mathrm{He}$ was thus prescribed prophylactic co-trimoxazole at a dose of 120 mg three times each week and referred for transfer. By transfer 10 days after initial admission, his respiratory status had deteriorated such that he needed $70 \%$ oxygen administered 
Table 1 Respiratory status and treatment in P carinii pneumonia complicating severe primary immunodeficiency

\begin{tabular}{|c|c|c|c|c|c|c|c|c|c|c|}
\hline \multirow[b]{3}{*}{ Child } & \multirow[b]{3}{*}{$\begin{array}{l}\text { Age } \\
\text { (months) }\end{array}$} & & & & \multicolumn{5}{|l|}{ After transfer } & \multirow[b]{3}{*}{ Outcome } \\
\hline & & \multicolumn{3}{|c|}{ Before transfer } & \multirow[b]{2}{*}{$\begin{array}{l}\text { Respiratory } \\
\text { pathogens on } \\
\text { BAL (NPS) }\end{array}$} & \multicolumn{2}{|c|}{ Respiratory support } & \multicolumn{2}{|l|}{ Treatment } & \\
\hline & & $\begin{array}{l}\text { Respiratory } \\
\text { pathogens }\end{array}$ & $\begin{array}{l}\text { Maximum } \\
\text { respiratory } \\
\text { support }\end{array}$ & $\begin{array}{l}\text { P carinii } \\
\text { treatment }\end{array}$ & & $\begin{array}{l}\text { Ventilated days } \\
\text { (max pressures) }\end{array}$ & $\begin{array}{l}\text { Days in } \mathrm{O}_{2} \\
\left(\max \mathrm{O}_{2}\right)\end{array}$ & $\begin{array}{l}\text { Co-trimoxazole } \\
\text { (mg/kg/day) } \\
\text { (days) }\end{array}$ & Other & \\
\hline 1 & 7 & None & Low flow $\mathrm{O}_{2}$ & $\begin{array}{l}\text { Co-trimoxazole } \\
120 \mathrm{mg} / \mathrm{kg} / \text { day }\end{array}$ & $P$ carinii & None & None & $120(14)$ & Pred/bud & Well \\
\hline 2 & 7 & PF3 & $25 \% \mathrm{O}_{2}$ & None & $\begin{array}{l}\text { P carinii }+ \text { PF3 } \\
\text { (PF3) }\end{array}$ & None & $7(25 \%)$ & $120(28)$ & Pred/bud & Died, PF3 \\
\hline 3 & 12 & None & $\begin{array}{l}\text { Vent } 36 / 3 \\
100 \% \mathrm{O}_{2}\end{array}$ & None & $\begin{array}{l}\text { P carinii }+ \\
\text { rhinovirus } \\
\text { (rhinovirus) }\end{array}$ & $24(36 / 7)$ & $35(100 \%)$ & $120(28)$ & $\begin{array}{l}\text { Pred/bud } \\
\text { surfactant } \\
\text { primaquine } \\
\text { clindamycin }\end{array}$ & $\begin{array}{l}\text { Died, G -ve } \\
\text { sepsis }\end{array}$ \\
\hline 4 & 6 & None & None & $\begin{array}{l}\text { Co-trimoxazole } \\
\text { prophylaxis }\end{array}$ & $\begin{array}{l}\text { P carinii } \\
(P \text { carinii } \\
\text { +moraxella })\end{array}$ & None & None & $120(21)$ & Pred & Well \\
\hline 5 & 10 & $\begin{array}{l}\text { P carinii on } \\
\text { lung biopsy }\end{array}$ & $\begin{array}{l}\text { Vent } 29 / 12 \\
100 \% \mathrm{O}_{2}\end{array}$ & $\begin{array}{l}\text { Co-trimoxazole } \\
120 \mathrm{mg} / \mathrm{kg} / \text { day } \\
\text { pentamidine }\end{array}$ & $\begin{array}{l}\text { Strep } \\
\text { pneumoniae }\end{array}$ & None & $\begin{array}{l}15 \\
(1.5 \mathrm{l} / \mathrm{min})\end{array}$ & $120(14)$ & $\begin{array}{l}\text { Pred/bud } \\
\text { pentamidine }\end{array}$ & $\begin{array}{l}\text { Died, G -ve } \\
\text { sepsis }\end{array}$ \\
\hline 6 & 10 & None & $70 \% \mathrm{O}_{2}$ & $\begin{array}{l}\text { Co-trimoxazole } \\
\text { prophylaxis }\end{array}$ & P carinii & $10(18 / 7)$ & $19(95 \%)$ & $120(14)$ & Pred/bud & Well \\
\hline 7 & 5.5 & Rhinovirus & $35 \% \mathrm{O}_{2}$ & None & $P$ carinii $+\mathrm{PF} 4$ & None & $23(35 \%)$ & $120(21)$ & Pred/bud & Died, PF4 \\
\hline 8 & 4.5 & None & $\begin{array}{l}\text { Vent } 17 / 5 \\
40 \% \mathrm{O}_{2}\end{array}$ & $\begin{array}{l}\text { Co-trimoxazole } \\
\text { prophylaxis }\end{array}$ & $P$ carinii $+\mathrm{PF} 3$ & None & None & $120(14)$ & Pred/bud & Died, PF3 \\
\hline 9 & 6 & PF1 & $\begin{array}{l}\text { Vent } 25 / 3 \\
100 \% \mathrm{O}_{2}\end{array}$ & $\begin{array}{l}\text { Co-trimoxazole } \\
120 \mathrm{mg} / \mathrm{kg} / \text { day }\end{array}$ & P carinii & $6(25 / 3)$ & $14(100 \%)$ & $120(21)$ & Pred/bud & Well \\
\hline 10 & 5 & None & $\begin{array}{l}\text { Vent } 28 / 10 \\
60 \% \mathrm{O}_{2}\end{array}$ & $\begin{array}{l}\text { Co-trimoxazole } \\
120 \mathrm{mg} / \mathrm{kg} / \text { day }\end{array}$ & $\begin{array}{l}\text { P carinii on lung } \\
\text { biopsy only }\end{array}$ & $17(28 / 10)$ & $27(80 \%)$ & $120(21)$ & Pred/bud & Died, HHV 6 \\
\hline
\end{tabular}

BAL, bronchoalveolar lavage; bud, nebulised budesonide; HHV, human herpes virus; NPS, nasopharyngeal secretions; Pred, prednisolone/methylprednisolone; PF1/ 3/4, parainfluenza virus 1,3 or 4; Vent, ventilated; $\mathrm{x} / \mathrm{y}$, pressures in $\mathrm{cm}_{2} \mathrm{O} ; \mathrm{G}$-ve, Gram negative.

through a head box. After transfer he deteriorated further and required ventilation. $P$ carinii was identified in bronchoalveolar lavage fluid; no other pathogens were identified. He was treated with co-trimoxazole at a dosage of 120 $\mathrm{mg} / \mathrm{kg}$ a day for 14 days. He also received methylprednisolone $2 \mathrm{mg} / \mathrm{kg}$ a day until extubation 10 days later when nebulised budesonide was added. Maximum ventilatory pressures were $18 / 7 \mathrm{~cm} \mathrm{H}_{2} \mathrm{O}$ and maximum fractional inspired oxygen was 0.95 . $\mathrm{He}$ required supplementary oxygen for a further nine days after extubation. The underlying diagnosis was $\mathrm{T}^{-} \mathrm{B}^{+}$SCID. After cytoreductive conditioning, bone marrow transplantation was undertaken with paternal $\mathrm{T}$ cell depleted marrow, and two years later he remains fit and well.

CASE B

A 5 month old Asian infant (patient 7 in table 1) presented to his local hospital with a three week history of cough and fever. His parents were first cousins but there was no family history suggestive of an immunodeficiency. His admission chest radiograph showed patchy infiltrates; no organisms were isolated from his nasopharyngeal secretions. He was treated with cefuroxime, flucloxacillin, and antituberculous therapy. Seven days after initial presentation he was transferred to his regional teaching hospital with deteriorating respiratory function. A repeat chest radiograph showed interstitial pneumonitis. He required ventilation three days later, and bronchoalveolar lavage was performed but no pathogens isolated. Peripheral blood lymphocyte marker analysis disclosed the absence of DR+ve cells, and hence empirical treatment with co-trimoxazole and methylprednisolone was commenced before transfer. At transfer he was ventilated with pressures of $28 / 10 \mathrm{~cm} \mathrm{H}_{2} \mathrm{O}$ with fractional inspired oxygen of 0.6. Repeat investigation of nasopharyngeal secretion and bronchoalveolar lavage fluid failed to identify an organism, and lung biopsy was performed, showing $P$ carinii. He received 21 days of co-trimoxazole at $120 \mathrm{mg} / \mathrm{kg}$ a day and 10 days of methylprednisolone at $2 \mathrm{mg} / \mathrm{kg}$ a day, weaning over the subsequent two weeks. Nebulised budesonide was also given. He was extubated 17 days after transfer and managed in room air 10 days later. His underlying diagnosis was MHC class II deficiency, and unfortunately he succumbed to human herpes virus 6 hepatitis before bone marrow transplantation could take place.

\section{Results}

PCP occurred in 10 of the 50 infants reviewed; five were white and five Asian.

Four of the Asian children were born into consanguineous first cousin marriages, and two families had histories of unexplained infant deaths. The infants' ages ranged from 4.5 months to 1 year at presentation (median 6.5 months). All had previously been seen in other hospitals, with failure to thrive, chronic diarrhoea, recurrent thrush, or pulmonary symptoms. The underlying diagnoses were $\mathrm{T}^{-} \mathrm{B}^{+}$ SCID (three), MHC class II deficiency (two), Omenn's syndrome (two), $\mathrm{T}^{-} \mathrm{B}^{-}$SCID (two), and $\mathrm{T}$ cell activation defect (one). In all infants, cough, recession, and tachypnoea were present and in part prompted the decision to investigate for an underlying immunodeficiency. However, the nature of the respiratory compromise varied greatly, as did the degree of support needed.

In only one infant had the diagnosis of PCP been confirmed before transfer. He was treated with 14 days of co-trimoxazole at $120 \mathrm{mg} / \mathrm{kg}$ a day followed by $120 \mathrm{mg}$ three times a week until a recurrence of his symptoms prompted a change to pentamidine. In eight infants, the 
diagnosis was made on bronchoalveolar lavage performed the day after transfer; one of these infants also had a positive nasopharyngeal secretion at Newcastle General Hospital. The remaining infant required lung biopsy for positive identification of $P$ carinii, after bronchoalveolar lavage failed to show any pathogens on two occasions. Those who were undiagnosed before transfer had received no specific treatment for PCP (three), prophylactic $\mathrm{CO}^{-}$ trimoxazole (three), or empirical high dose co-trimoxazole (three). In four infants coexistent viral respiratory pathogens were isolated, and in two others bacterial pathogens were also found (table 1).

The infants in whom $P$ carinii was detected after transfer were treated with co-trimoxazole at $120 \mathrm{mg} / \mathrm{kg}$ a day for 14 (three), 21 (four), or 28 (two) days, dependent on the speed of resolution of signs and symptoms. All infants received intravenous or oral steroids, initially at $2 \mathrm{mg} / \mathrm{kg}$ a day for a minimum of nine days. Infants with continuing respiratory difficulty and coexistent viral pathogens often remained on steroid treatment throughout the transplant period. In addition, nebulised budesonide at a dose of $2 \mathrm{mg}$ four times a day was used in nine infants. One infant was particularly difficult to treat and received two doses of surfactant as well as the addition of primaquine and clindamycin for 14 days as second line treatment for $P$ carinii (patient 3 in table 1).

All infants with PCP were successfully treated. The four infants ventilated after transfer were all successfully extubated (median duration of ventilation after transfer 13.5 (range 6-24) days), and all were eventually managed in room air (median duration of oxygen dependency 14.5 (range 0-35) days). One infant died from human herpes virus 6 hepatitis before bone marrow transplantation but the other nine survived to bone marrow transplantation. Four infants were cured by bone marrow transplantation, and at long term follow up (23 to 72 months) are alive and well with no continuing respiratory problems and good immune function. Five patients died after bone marrow transplantation, while still inpatients, from causes unrelated to $P$ carinii (parainfluenza virus pneumonitis (three) and Gram negative sepsis (two)).

\section{Discussion}

Ten of a cohort of 50 infants with SCID had $P$ carinii infection at diagnosis. This is in keeping with previous findings of $P$ carinii in 19 of 117 infants with SCID. ${ }^{3}$ About 30 infants a year are born in the United Kingdom with SCID, of whom six can therefore be expected to be infected with $P$ carinii and be symptomatic. They are likely to present with respiratory difficulty associated with other features suggesting an immune defect. Many paediatricians will consider possible underlying HIV infection and then investigate for opportunistic pathogens such as $P$ carinii. However, outside London only 122 cases of mother to infant transmission of HIV have been recognised to date, ${ }^{4}$ about seven cases a year in the whole of the rest of the United Kingdom. Of these infants, four can be expected to develop $P$ carinii infection in their first year of life. ${ }^{5}$ Most of these cases of vertically transmitted infection will come from identifiable at risk groups such as intravenous drug abusers or sub-Saharan African mothers. Outside London and these high risk groups, an infant with PCP is therefore more likely to have a primary immune defect and should be urgently investigated for this. This is particularly true for infants born to related parents, for whom there is a higher risk of an autosomal recessive primary immune defect.

In all of the cases studied here, respiratory signs were present and a primary immune defect was strongly suspected before transfer, but in only one infant had the respiratory pathogen been detected. Routine respiratory specimens are not processed for $P$ carinii, and hence the two diagnostic steps of likely immunodeficiency and possible $P$ carinii must be made together and specific immunofluorescence testing requested. Suitable specimens must also be sent. In adult HIV patients, $P$ carinii was detected in induced sputum in $90 \%$ of those ultimately shown to have PCP. ${ }^{6}$ Children, however, swallow most of their sputum, and nasopharyngeal secretions may not contain material from the lower respiratory tract. In this series nasopharyngeal secretion was positive in only one of 10 cases of confirmed PCP. Bronchoalveolar lavage should therefore be performed in all such infants with respiratory distress and certainly if ventilation is required. Progression to open lung biopsy should be seriously considered in the presence of respiratory distress without an identified pathogen after the above measures. ${ }^{7}$ The identification of one pathogen from the respiratory tract should not deter investigation for a co-pathogen, which was found in six of the 10 infants in our series. This high proportion of co-pathogens has previously been reported in HIV positive children with $P$ carinii or cytomegalovirus pneumonia, in whom 11 of 19 had co-pathogens. ${ }^{8}$ Only after identification of all pathogens can appropriate management decisions be made.

In infants with a primary immune defect, chest radiograph changes (especially of bilateral diffuse infiltrates), and respiratory distress in whom no specific pathogen can be detected despite full investigation, empirical treatment with co-trimoxazole at $120 \mathrm{mg} / \mathrm{kg}$ a day should be given. One infant in this series had progressive respiratory failure due to PCP despite prophylactic dose co-trimoxazole, illustrating that, in established PCP, a dose of $120 \mathrm{mg} / \mathrm{kg}$ a day is required to halt progression and reverse respiratory compromise.

In all 10 infants, treatment of the $P$ carinii infection was successful, including five who were ventilated, which compares favourably with previous studies in which mortality from $P$ carinii was $100 \%$ if the infants were ventilated. ${ }^{9}$ Four of 10 infants with $P$ carinii infection and an underlying diagnosis of SCID were eventually cured by bone marrow transplantation. In a multicentre European study ${ }^{10}$ including patients from our centre, the overall success rate for bone marrow transplantation in SCID 
was $70 \%$, but only $30 \%$ for those with respiratory disease at presentation (the overall figure includes those diagnosed at birth who have an excellent prognosis as there is no pre-existing infection). All the deaths in this series were unrelated to $P$ carinii infection, and nearly half the infants were cured by bone marrow transplantation and lead normal lives with full immune function. Infants with SCID should be referred for bone marrow transplantation as soon as possible, highlighting the well documented but only recently acknowledged fact that SCID is a paediatric emergency. ${ }^{11}$

CONCLUSION

PCP is a common but often unrecognised presenting feature of severe $T$ cell immune defects and should be sought intensively in the presence of respiratory distress in this population. Conversely, interstitial lung infiltrates not responding to antibiotics active against intracellular pathogens, in particular if associated with other features of immunodeficiency such as diarrhoea, thrush, and failure to thrive, should prompt the performance of a bronchoalveolar lavage and investigation for a primary immune defect and HIV infection. Once detected, PCP should be aggressively treated; resolution of symptoms and ventilator or oxygen dependency can be expected. Severe $P$ carinii infection alone in a child with SCID does not lessen the chances of successful bone marrow transplantation which can lead to normal life and full immunity.

1 Weltzer PD, Scultz MG, Western KA, Robbins JB. Pneumocystis carinii pneumonia and primary immune deficiency cystis carinii pneumonia and primary immune deficiency
diseases of infancy and childhood. $\mathcal{F}$ Pediatr 1973;82:41622 .

2 Tasker RC, Wilkinson K, Slater TJ, Novelli V. Unsuspected Pneumocystis carinii pneumonia and vertically acquired HIV infection in infants requiring intensive care. $B M F$ 1994;308:462-3.

3 Stephan JL, Vlekova V, Le Deist F, et al. Severe combined immunodeficiency; a retrospective single-centre study of clinical presentation and outcome in 117 patients. $\mathcal{F}$ Pediatr 1993;123:564-72.

4 Aids and HIV infection in the United Kingdom: monthly report. Commun Dis Rep CDR Wkly 1999;9:85-6.

5 Oxtoby MJ. Perinatally acquired human immunodeficiency virus infection. Pediatr Infect Dis f 1990;9:609-19.

6 Masur H, Lane HC, Kovacs JA, Allegra CJ, Edman JC. Pneumocystis pneumonia: from bench to clinic. Ann Intern Med 1989;11:813-26.

7 Hughes WT. Pneumocystis carinii pneumonia: new approaches to diagnosis, treatment and prevention. Pediatr proaches to diagnosis, treatm
Infect Dis f 1991;10:391-9.

8 Vernon DD, Holzman BH, Lewis P, Scott GB, Birriel JA, Scott MB. Respiratory failure in children with acquired immunodeficiency syndrome and acquired immunodeficiency syndrome related complex. Pediatrics 1988;8: 223-8.

9 Deerojanawong J, Chang AB, Eng PA, Robertson CF, Kemp AS. Pulmonary diseases in children with severe combined immune deficiency and DiGeorge syndrome. Pediatr Pulmonol 1997;2:324-30.

10 Fischer A, Landais P, Friedrich W, et al. European experience of bone marrow transplantation for severe combined immunodeficiency. Lancet 1990;336:850-4.

11 Rosen FS. Severe combined immunodeficiency: a paediatric emergency. $\mathcal{F}$ Pediatr 1997;130:345-6. 